\title{
Chrystocentryzm maryjny w przepowiadaniu
}

Wśród wielu tematów ukazujących różne aspekty chrystocentryzmu w przepowiadaniu Kościoła nie może zabraknąć refleksji dotyczącej kaznodziejstwa maryjnego, czyli dania odpowiedzi na pytanie, jak mówić o Maryi, uwzględniając Jej szczególną rolę w zbawczym planie Boga, a jednocześnie pamiętając, że kaznodziejstwo maryjne ma proklamować dzieło Boga w Chrystusie. To jest fundament, bowiem $\mathrm{w}$ sensie ścisłym istnieje $\mathrm{w}$ chrześcijaństwie tylko przepowiadanie chrystocentryczne. Jeżeli zabrakło by tego fundamentu nie będzie skuteczności przepowiadania, bowiem zależy ona od obecności Chrystusa w głoszonym słowie.

On przez swego Ducha jest Tym, który oświeca, proponuje zaprasza. On czeka z darem przebaczenia i życia. Maryja natomiast stanowi przedmiot głoszenia. O Niej mówimy, Jej tajemnice rozważamy, ale Ona nie jest w słowie aktualnie obecna, choć jest blisko nas i wstawia się za nami. [...] Jeśli więc to, co głosimy ma być słowem Boga, mamy tylko jedno rozwiązanie: głosić tak, jak 
sam Bóg nam się objawił. Wiemy zaś, że najdoskonalej przemówił do nas przez Syna. Płynie stąd wniosek, że cokolwiek mówimy o Maryi, musi mieć jakiś związek z Chrystusem. ${ }^{1}$

Wydaje się to czymś oczywistym i niepodważalnym, co znajduje potwierdzenie $\mathrm{w}$ wielu najnowszych publikacjach na ten temat oraz drukowanych kazaniach maryjnych. Warto tu zaznaczyć, że jeszcze na początku lat dziewięćdziesiątych ubiegłego wieku przepowiadanie maryjne w niewielkim tylko stopniu uwzględniało wymiar chrystocentryczny ${ }^{2}$.

Niewątpliwie na aktualny stan kaznodziejstwa maryjnego, tak w wymiarze teoretycznym jak i praktycznym, wpłynęły II Sobór Watykański, dokumenty posoborowe Kościoła i współczesna mariologia. Żeby więc ukazać aktualne zagadnienia związane z chrystocentryzmem maryjnym w przepowiadaniu, trzeba będzie odwołać się do tych najważniejszych dokumentów oraz komentarzy teologicznych. Nie będzie to jednak pełna prezentacja tych dokumentów, ale skupienie się na problemach związanych ściśle z chrystocentrycznym wymiarem przepowiadania.

\section{Historiozbawczy obraz Maryi w dokumentach Kościoła}

Zasadniczym rysem mariologii soborowej jest ukazanie Maryi w perspektywie historii zbawienia, której centrum jest Jezus Chrystus. Sam tytuł VIII rozdziału Konstytucji dogmatycznej o Kościele: Błogosławiona Maryja Dziewica Boża Rodzicielka w tajemnicy Chrystusa

1 J. Nalaskowski, Jasnogórska posługa słowa Bożego w świetle VIII rozdziału "Lumen gentium", w: Studia Claramontana, Jasna Góra 1982, s. 26.

2 Por. T. Lewandowski, Kaznodziejstwo maryjne, „Przegląd Pastoralno-Homiletyczny”, 4 (2000), s. 39-57. 
i Kościoła zawiera w sobie dwa podstawowe, charakterystyczne w całości prezentowanej nauki elementy. Tytuł „Boża Rodzicielka” wyraża główną prawdę mariologii, jaką jest Boże macierzyństwo Maryi. Drugi charakterystyczny termin to „tajemnica”, użyty w liczbie pojedynczej dla podkreślenia, że Chrystus i Kościół w dziejach stanowią jedno misterium ${ }^{3}$.

W tak zarysowanej perspektywie szczególnych powiązań Maryi z Chrystusem i Kościołem jawi się Jej wyjątkowe miejsce w tajemnicy zbawienia. Maryja jest ukazana jako Matka Odkupiciela, którego dzieło trwa w Kościele, oraz jako Współpracownica, która „samą siebie oddała całkowicie [...] osobie i dziełu swego Syna [...], służąc wraz z Jezusem i w zależności od Niego tajemnicy odkupienia (KK 57).

Udział Maryi w zbawczym planie Boga sobór ukazuje w oparciu o objawiony przekaz Pisma Świętego i Tradycji. Dzięki temu Stary Testament przestał być traktowany jako skarbnica obrazów, które można dowolnie do Maryi akomodować, lecz ukazany jest jako autentyczne objawienie, przybliżające postać Niewiasty, w pełni zrozumiałą w świetle Nowego Testamentu. Odniesienie się do biblijnego przekazu prowadzi do stwierdzenia, że Maryja jest obecna we wszystkich etapach historii zbawienia. W Jej osobie dawny lud obietnic przemienia się w nowy lud łaski i już dokonanego zbawienia. Maryja jest więc własnością Starego Przymierza, jest obecna w ziemskiej działalności Jezusa, wreszcie należy do czasu Kościoła i swoje funkcje zakończy z powtórnym przyjściem Chrystusa.

Oprócz biblijnego, charakterystycznym dla Soboru jest akcent patrystyczny. Dowartościowano zasadniczą prawdę, że ojcowie Kościoła

3 W prezentacji dokumentów Kościoła wykorzystałem w dużej mierze wcześniejsze moje publikacje, a zwłaszcza Implikacje homiletyczne soborowej mariologii, „Ateneum Kapłańskie” 79 (1987) t. 108 z. 467, s. 65-73; Mariologia soborowa w kaznodziejstwie polskim, w: Matka Jezusa pośród pielgrzymujq̨cego Kościoła, red. J. Gajek i K. Pek, Warszawa 1993, s. 175-204; Polskie kaznodziejstwo maryjne po II Soborze Watykańskim, w: Z zagadnień współczesnej homiletyki, red. W. Przyczyna, Kraków 1993, s. 146-203. 
są najbardziej dawnymi świadkami głoszonych prawd i wiary Kościoła. W oparciu o tę zasadę, Lumen gentium szuka potwierdzenia teologii maryjnej w nauce patrystycznej, co czyni zaraz po Piśmie Świętym (por. KK 55). Powołując się na ojców Kościoła, Sobór akcentuje godność macierzyństwa Maryi, dobrowolność współpracy w dziele zbawienia, przypomina paralelę Ewa-Maryja, podkreśla istotny związek pomiędzy cielesnym macierzyństwem Maryi i jej osobowym - wewnętrznym stosunkiem do Słowa Wcielonego (por. KK 53), ukazuje także nowe relacje Maryi do Kościoła (por. KK 53 i 63).

VIII rozdział Konstytucji dogmatycznej o Kościele nosi wyraźne ślady ścierania się dwóch koncepcji mariologicznych: chrystotypicznej i eklezjotypicznej. W drugiej części Lumen gentium, mówiącej o roli Błogosławionej Dziewicy w ekonomii zbawienia, dochodzi do głosu koncepcja mariologii chrystotypicznej, natomiast w części trzeciej - Błogosławiona Dziewica i Kościół - ujawnił się kierunek eklezjotypiczny i ta część rozdziału uważana jest za największe osiągnięcie Vaticanum II.

Szczególnie uwypukloną formą relacji Maryi do Kościoła jest jej wzorczość wobec Ludu Bożego. Ta wzorczość występuje w kolejnych etapach Jej istnienia - w Niej, od chwili zwiastowania aż do śmierci Chrystusa, jest ukryty cały Kościól jako wspólnota łaski i świętości ze Zbawicielem. Dziewicze macierzyństwo Maryi w stosunku do Chrystusa ma swój odpowiednik w posłannictwie, jakie pełni Kościół wobec ludzi. Tak więc w historii zbawienia Maryja i Kościół pełnią najwspanialsze zadania: zrodzenia i wychowania w duszach ludzkich Chrystusa (por. KK 53, 63, 64).

Maryja jest także osobiście wzorem świętości Kościoła. Kościół widzi w Niej ideał wszystkich cnót, zwłaszcza wiary, posłuszeństwa i macierzyńskiej miłości. Jej wzorczość w relacji do Kościoła sięga aż wiecznej chwały. Jest Ona obrazem i zaczątkiem tej świętości, którą Kościół osiągnie w paruzji. I taka wizja Maryi, ukazująca z jednej strony Jej związek z całą ludzkością, a z drugiej Jej niepowtarzalne 
dostojeństwo wskazuje na drogę wyjścia ze sporu między chrystotypistami i eklezjotypistami. Maryja przyjmuje dary i pielgrzymuje do Boga, ale równocześnie posiada jedyną w swoim rodzaju łączność z Chrystusem, co czyni Ją pierwowzorem Kościoła i uzasadnia Jej uczestnictwo w dziele Syna.

Dokument soborowy nie stawia więc Maryi ponad Kościołem, ale ukazuje Ją obecną w Kościele. Swoje funkcje i zadania realizuje Ona wewnątrz tajemnicy Kościoła. Dzięki wyjątkowemu współdziałaniu w dziele zbawienia przez posłuszeństwo, wiarę, nadzieję i miłość weszła z nim w szczególne relacje, stała się naszą Matką w porządku łaski. Macierzyństwo to „trwa nieprzerwanie od chwili jej niezawodnego przyzwolenia danego przy zwiastowaniu i ponowionego bez wahania pod krzyżem, aż do osiągnięcia wiekuistej pełni przez wszystkich wybranych" (KK 62). Orędownictwo, pośrednictwo, niesienie pomocy są jakby formami jej macierzyństwa w stosunku do ludzi.

Sobór omawiając problem macierzyństwa Maryi w porządku łaski w nowy sposób ukazał kwestię pośrednictwa maryjnego. Sam tytuł „Pośredniczka” został wymieniony pomiędzy innymi tytułami (por. KK 62) bez jego rozszerzania określeniem „łask wszelkich”. Pośrednictwo Maryi Sobór tłumaczy w sensie wstawiennictwa, przy jednoczesnym przypomnieniu prawdy o jednym Pośredniku (por. KK 61). W konsekwentny sposób VIII rozdział pomija wyrażenie „Pośredniczka do Pośrednika” i podkreśla, że pośrednictwo Maryi nie stoi na przeszkodzie bezpośredniemu zjednoczeniu wiernych z Chrystusem. Zaznacza jednocześnie, że pośrednicząca funkcja stworzeń w dziele zbawienia, nie wyklucza jedynego pośrednictwa Chrystusa, tak jak kapłaństwo wiernych nie wyklucza jedynego kapłaństwa Chrystusa oraz dobroć stworzeń nie przekreśla prawdy, że sam Bóg jest dobry (por. KK 63).

Ojcowie soborowi, ukazując Maryję w tajemnicy Chrystusa i Kościoła, podają także podstawowe elementy nauki o kulcie Matki Bożej i określają go jako specjalny (por. KK 66). Dając pierwszeństwo kul- 
towi liturgicznemu, postulują roztropność w doborze form pobożności maryjnej, aby nie zrazić nimi braci odłączonych oraz propagują kult włączony w życie i mobilizujący do wierności Chrystusowi.

W ten sposób Sobór nakreślił ramy i wytyczył kierunki rozwoju mariologii oraz kultu maryjnego. W ten nurt soborowy włączył się papież Paweł VI wydając adhortację Marialis cultus poświęconą teologii oraz pastoralnym aspektom kultu i pobożności maryjnej. Zasadniczym przedmiotem tej adhortacji jest teologia kultu maryjnego i to $\mathrm{w}$ ramach zreformowanej liturgii. Papież zdecydowanie stwierdza, że kult maryjny potrzebuje odnowy. O jej potrzebie decyduje wiele racji, wśród nich zachowanie wierności Tradycji, uwrażliwienie na współczesność, przemiany w przeżywaniu przez współczesnego człowieka relacji do Boga oraz rozwój teologii i innych nauk ${ }^{4}$.

Według Marialis cultus kult Maryi będący częścią kultu Chrystusa, a więc włączony w nurt jednego kultu chrześcijańskiego, powinien uwzględnić następujące zasady: trynitarną, chrystologiczną, pneumatologiczną i eklezjalną. A zatem pobożność maryjna musi posiadać charakter trynitarny; w czci oddawanej Maryi powinno być więcej Chrystusa i więcej Ducha Świętego. Nie można odłączać Maryi od Kościoła, ale widzieć Ją w Kościele i naśladować jako jego wzór.

Oprócz powyższych zasad teologicznych adhortacja podaje także cztery normy praktyczne: biblijną, liturgiczną, ekumeniczną oraz antropologiczną. To znaczy: do pobożności maryjnej trzeba wprowadzić więcej Pisma Świętego i wierności jego orędziu, podporządkować i uzgadniać z liturgią, unikać niewłaściwych form, które zrażają do katolicyzmu oraz przedstawić Maryję jako wzór do naśladowania. Właśnie naśladowanie stanowi zasadniczy kierunek postulowanych przemian. Papież wskazuje na Maryję jako wzór do naśladowania. Czcić Maryję, to tak jak Ona zasłuchać się w słowo Boże, rozważać

4 Por. S. C. Napiórkowski, Matka mojego Pana, Opole 1988, s. 14n. 
je w swoim sercu, tak jak Ona otwierać się na Ducha Świętego i być Jego narzędziem, tak jak Ona całkowicie oddać się Chrystusowi i być Jego sługą, tak jak Ona bez reszty poświęcić się sprawom Chrystusa i Jego Królestwu, tak jak Ona spieszyć z pomocą potrzebującym. Trzeba się w Nią wpatrywać jako nowego człowieka i przemieniać się na Jej wzór. Naśladowanie Bogarodzicy powinno prowadzić do dojrzałości chrześcijańskiej, przez zdynamizowanie życia religijnego i działalności apostolskiej.

Kolejne impulsy dla rozwoju teologii maryjnej i maryjnego kultu płyną z encykliki Jana Pawła II Redemptoris Mater. Ta biblijna medytacja podejmuje refleksję nad postacią Matki Odkupiciela w Jej szczególnym zjednoczeniu z Chrystusem, nad relacją Maryi do Kościoła jako wspólnoty wierzących i tajemnicy „pośrednictwa macierzyńskiego”. Przy czym wiodącymi tematami są: wiara Maryi i pośrednictwo.

W Redemptoris Mater otrzymujemy wszechstronne spojrzenie na wiarę Maryi, która na wielu etapach jej życia była wiarą heroiczną. Jej „pielgrzymka wiary” rozpoczęła się w chwili Zwiastowania i trwała aż po „kenozę wiary” przeżytą u stóp krzyża (por. RM 14-18). Wiara Maryi jest podobną do wiary Abrahama, który uwierzył wbrew nadziei. Matka Odkupiciela idzie drogą posłuszeństwa okazując „pełną uległość rozumu i woli wobec Boga objawiającego” (KO 5). W ten sposób przez ból, cierpienie oraz ofiarę swojego życia realizuje swoje posłannictwo.

Słusznie przeto w owym wyrażeniu „Błogosławionaś, któraś uwierzyła”, możemy upatrywać ,jakby klucz”, który otwiera nam wewnętrzną prawdę Maryi; Tej, którą anioł przy zwiastowaniu pozdrowił jako „łaski pełną”. (RM 19)

Poprzez taką postawę wiary Maryja wchodzi w tajemnicę Chrystusa oraz wiąże się z Nim na zawsze i dlatego ma Ona być wzorem naszej wiary, a Jej droga wiary naszą drogą. 
Wiara Maryi nie sprowadza się tylko do tajemnicy Chrystusa. Przez wiarę jest Ona obecna także w tajemnicy Kościoła. Jej wiara „staje się wciąż poniekąd wiarą pielgrzymującego ludu Bożego" (RM 28). Jak wiara była dla Maryi warunkiem i drogą do Bożego i duchowego macierzyństwa, tak dla Kościoła Ona sama jest przede wszystkim najznakomitszym wzorem wiary i posłuszeństwa. Dlatego przysługująca Maryi ze względu na Jej wiarę wzorczość w relacji do Kościoła jest czymś więcej niż tylko zwykłym przykładem do naśladowania ${ }^{5}$.

Drugim bardzo ważnym tematem encykliki, który ma istotne znaczenie zarówno dla teologii jak i dla duszpasterstwa, jest problem pośrednictwa. Otóż Jan Paweł II w sposób bardzo wyraźny przypomina naukę Kościoła, że Pośrednik jest jeden, natomiast jest wiele sposobów uczestniczenia w tym jedynym pośrednictwie Chrystusa. A zatem Ojciec św. podchodzi do zagadnienia pośrednictwa maryjnego podobnie jak II Sobór Watykański, przyjmując za punkt wyjścia prawdę o Bożym macierzyństwie. To właśnie macierzyństwo jest źródłem Jej szczególnego pośrednictwa, a jednocześnie stanowi ono jego zasadniczą cechę. W ten sposób pośrednictwo Maryi „posiada specyficznie macierzyński charakter, który wyróżnia je od pośrednictwa innych istot stworzonych" (RM 38). Dlatego też Jan Paweł II zastępuje tradycyjnie stosowany termin „pośrednictwo powszechne” na „macierzyńskie”, wskazując przez to nie na jego zakres lecz na szczególny charakter. Terminem „macierzyństwo” określa papież całość zaangażowania Maryi w zbawcze dzieło Jej Syna. W ten sposób prowadzi do połączenia w jedno tego, co stanowiło niegdyś trzy rozłączne etapy pośrednictwa: wcielenie, Kalwaria, czas Kościoła. Maryjne pośrednictwo nie wyczerpuje się w samym pośrednictwie w relacji do Chrystusa, ale domaga się ono macierzyństwa w relacji do nas,

5 T. Siudy, Wiara - „jakby klucz" do prawdy o Maryi, w: Matka Odkupiciela, red. S. C. Napiórkowski, Lublin 1993, s. 78. 
czyli macierzyństwa w porządku łaski. Maryja jest ściśle związana z tajemnicą Chrystusa i Kościoła, dlatego po macierzyńsku współdziała w zbawieniu, troszcząc się, by wszyscy jeszcze bardziej przylgnęli do Zbawiciela. Dlatego pośrednictwo maryjne, to pośrednictwo: „przez macierzyństwo”, „przez uczestnictwo”, „przez współdziałanie”, „przez wstawiennictwo" i nie jest ono koniecznym warunkiem naszego spotkania z Chrystusem, jedynym Pośrednikiem, ono to spotkanie umacnia i udoskonala ${ }^{6}$.

Redemptoris Mater jednoznacznie uczy, że osoby Maryi nie należy pojmować jako pośredniej instancji między nami a Bogiem, jako Pośredniczki „do Chrystusa”, bowiem Jej pośrednictwo zakorzenione jest w pośrednictwie Jej Syna, jest pośrednictwem „w Chrystusie”. Uświadamia ona, że z Maryją idziemy do Chrystusa, Ona stoi i podąża na czele ludu Bożego; często szliśmy „do Maryi”, dziś idziemy z Maryją do Chrystusa. Jest wezwaniem do komplementarności dwu haseł: „Do Chrystusa przez Maryję" i „Do Maryi przez Chrystusa”. A zatem trzeba widzieć Maryję w misteriach Chrystusa, „by poprzez nie dochodzić do poprawnej teologicznie ikony Matki i służebnicy Pańskiej" 7 .

W prezentacji dokumentów Kościoła nie może zabraknąć Katechizmu Kościoła Katolickiego, który dopełnia soborowe i posoborowe nauczanie Kościoła o Matce Bożej. W tym miejscu zostanie zwrócona uwaga jedynie na podkreślenie elementów związanych z tematem chrystocentryczności w przepowiadaniu. W Katechizmie przez zastosowanie zasady hierarchii prawd treści maryjne zostały ukazane w perspektywie chrystologicznej. W nauczaniu o Matce Chrystusa dokument podkreśla obecność Maryi w historii zbawienia, Jej postawę wiary, Jej obecność w całym życiu Chrystusa, Jej otwarcie na

6 Por. W. Łaszewski, Pośrednictwo szczególne i wyjątkowe, w: Matka Odkupiciela, dz.cyt., s. 91n.; S. C. Napiórkowski, Pośredniczka w Chrystusie, w: tamże, s. 195n.

7 S. C. Napiórkowski, Pierwsza chrześcijanka i przewodniczka pielgrzymującego Ludu, w: Kościół czci Matkę swego Pana, red. W. Siwak, Przemyśl 2003, s. 136n. 
działanie Ducha Świętego, który realizuje w Niej zbawczy plan Ojca. Istotne jest także podkreślenie obecności Maryi w tajemnicy Kościoła w wymiarze wzorczości i macierzyństwa, z zaznaczeniem, że źródłem relacji Maryi z Kościołem jest Jej ścisła łączność z Chrystusem, zapoczątkowana na ziemi i udoskonalona w chwale nieba. Należy także zauważyć, że Katechizm Kościoła Katolickiego wskazuje na Maryję jako wzór życia w Chrystusie i opowiada się za liturgicznym kultem Matki Jezusa. A zatem katechetyczny obraz Maryi włączony jest integralnie w przepowiadanie o Chrystusie. Przepowiadanie o Maryi musi mieć wymiar trynitarny, historiozbawczy i eklezjalny. Dla Kościoła pozostaje jako Nauczycielka i Matka. Od Niej Kościół się uczy przeżywania najważniejszych prawd wiary, przyjmowania ich i stosowania w codziennym życiu, razem z Nią miłowania Jezusa ${ }^{8}$.

\section{Współczesna mariologia wyzwaniem dla przepowiadania słowa Bożego}

Zarysowany wyżej obraz Maryi, zawarty w wybranych, ale najistotniejszych dokumentach Kościoła, będących kontynuacją myśli II Soboru Watykańskiego, otwiera nowe perspektywy przed głosicielami słowa Bożego. Dzięki ogromnej pracy szczególnie dwóch teologów, Stanisława C. Napiórkowskiego ${ }^{9}$ i Józefa Kudasiewicza ${ }^{10}$, to nowe spojrzenie na rolę Maryi w dziele zbawienia zaczyna przenikać do przepowiadania. Posiadamy już sporo publikacji przenoszących

8 J. Kumala, Maryja w nowym „Katechizmie Kościoła Katolickiego", w: Matka Jezusa pośród pielgrzymującego Kościoła, dz. cyt., s. 225-240.

9 Tylko niektóre pozycje tegoż autora zostały tutaj zasygnalizowane, niewątpliwie ojciec Napiórkowski ma największy wkład w kształtowanie polskiej mariologii po Il soborze watykańskim.

10 Zwracam uwagę szczególnie na dwie pozycje: J. Kudasiewicz, Matka Odkupiciela, Kielce 1991; tenże, Oto Matka twoja. Biblijny katechizm maryjny, Kielce 2007. 
konkretne implikacje homiletyczne współczesnej mariologii. Coraz więcej teologów kreśli teologicznie poprawną, tzn. opartą na przekazie biblijnym, ikonę Maryi, która zaczyna funkcjonować w polskich homiliach i kazaniach. O taką poprawną teologicznie ikonę Maryi w kaznodziejstwie zadbał m.in. ks. Wacław Siwak, i to w wymiarze źródłowym, metodologicznym i treściowym ${ }^{11}$. Poprawna kaznodziejska ikona maryjna powinna być ikoną biblijną, patrystyczną, liturgiczną i magisterialną. Nauczanie o Maryi musi posiadać nieustanne odniesienie do historii zbawienia, czyli pozostawać w perspektywie ukazującej Ją w relacji do Trzech Osób Boskich (perspektywa trynitarna, chrystologiczna, pneumatologiczna), w relacji do Kościoła (perspektywa eklezjologiczna), ludzkości (antropologiczna), wszechświata oraz innych rzeczywistości.

Skoro w szczególny sposób koncentrujemy się na wymiarze chrystocentrycznym maryjnego przepowiadania, to ważna jest sugestia tegoż autora, aby ukazywać Maryję w oparciu o idę̨ korelacji, gdzie poznanie jednego z korelatów ułatwia poznanie drugiego. Zdaniem ks. Siwaka, mówiąc o korelacji Bóg Ojciec-Maryja, trzeba zwrócić uwagę na chrystologiczne centrum tego związku.

To ze względu na Chrystusa Maryja została przez Ojca odwiecznie wybrana do Bożego macierzyństwa, wraz z całym światem powołana do bytu, obdarowana wszelkimi łaskami. Ona sama jawi się jako: Ikona macierzyńska Ojcostwa Boga; Ikona miłosierdzia i czułości Ojca; Ikona ojcowskiego zawierzenia. Maryja jako „Córa Boga Ojca” jawi się jako szczególne Dziecko Boże (usynowione w Synu), wyjątkowo obdarowane miłością Ojca. ${ }^{12}$

11 W. Siwak, Jaka ikona Maryi w przepowiadaniu peregrynacyjnym, w: Kościół czci Matkę swego Pana, dz. cyt., 171-189; tenże, O poprawna teologicznie ikonę Maryi w kaznodziejstwie, "Studia Pastoralne” 7 (2011), s. 277-291.

12 W. Siwak, o poprawnq teologicznie ikonę Maryi..., dz. cyt., s. 282. 
Korelację Syn Boży-Maryja, dobrze oddaje od dawna znana formuła „Przez Maryję do Jezusa” uzupełniona przez Jana Pawła II formułą „Przez Jezusa do Maryi”. To właśnie w tajemnicy Chrystusa wyjaśnia się tajemnica Maryi, kto znajduje Chrystusa, znajduje także Maryję, ponieważ Ewangelia o Jezusie Chrystusie przekazuje również orędzie o Matce Pana i w takim sensie Jezus niezawodnie prowadzi do Maryi. Poznając tajemnicę Maryi lepiej rozumiemy tajemnicę Syna Bożego. Ta współzależność odnosi się także do wymiaru kultycznego, pozwala zrozumieć istotę kultu chrześcijańskiego ${ }^{13}$.

Doskonałą aplikacją powyższej formuły jest misterium Wcielenia wraz z istotowo powiązanym z nim misterium Bożego macierzyństwa, który jako dogmat mariologiczny możemy odczytywać w kluczu chrystologicznym, gdzie tytuł „Matka Boga” mówi nam o prawdziwym człowieczeństwie Chrystusa, Jego prawdziwym Bóstwie oraz Jego osobowej jedności. Ale możemy również odczytywać chrystologiczny dogmat Wcielenia w kluczu mariologicznym, w którym podkreślamy wyniesienie Maryi do najwyższego urzędu i godności oraz Jej szczególną rolę w dziele pojednania Boga z ludzkością. Ważnym elementem relacji Maryja-Syn jest udział Jej jako Matki w odkupieńczym dziele Syna. Udział ten, wyrażony w aspekcie funkcjonalności, to misterium Jej macierzyństwa, poprzez które umożliwiła Synowi Bożemu dokonanie dzieła naszego odkupienia w ludzkim ciele. Biorąc pod uwagę aspekt aktywności, można sprowadzić go do Jej fiat, wypowiedzianego Zwiastowaniu i przez całe życie, aż po krzyż Jezusa. Maryjne fiat posiada ważny walor historiozbawczy, analogicznie do Jezusowego fiat wypowiadanego Ojcu w zbawczych misteriach (gł. Wcielenia i Śmierci). ${ }^{14}$ 
Żeby dobrze zrozumieć i właściwie ująć w przepowiadaniu te korelacje Syna i Matki należy ukazywać pełny obraz Jezusa Chrystusa i ewangeliczny obraz Maryi ${ }^{15}$.

W centrum poprawnie ustawionej świadomości chrześcijanina musi stać Jezus Chrystus - Odkupiciel, Zbawiciel, Pośrednik, Kapłan, Prorok, Pasterz i Przyjaciel. Bez Chrystusa nie ma zbawienia, odkupienia, nie ma chrześcijaństwa, nie ma Kościoła i Matki Kościoła. Jezus Chrystus jest uosobieniem miłosierdzia Ojca, jest pełnią Objawienia, jedyną szansą i ocaleniem człowieka, najskuteczniejszym Orędownikiem nieustannie obecnym pośród wspólnoty odkupionych. Jezus jest zawsze bliski człowiekowi, jemu najbliższy. To On buduje wspólnotę swoich uczniów, wyznacza funkcje i rozdziela dary. Każdy w Jezusowej wspólnocie ma swoje miejsce i zadania, również Maryja. Kto w pełni spogląda na Jezusa Odkupiciela, ten zobaczy i zachwyci się Jego Matką ${ }^{16}$.

Mamy więc szukać obrazu Maryi w tajemnicy Chrystusa, czyli w Ewangelii. Przekonującą ilustrację tezy „przez Jezusa do Maryi” stanowi perykopa Mędrców ze Wschodu (Mt 2, 1-12). Znaleźli oni Jezusa, ale równocześnie z Nim Jego Matkę. Tą samą drogą doszedł do Maryi napełniony Duchem Świętym starzec Symeon. Temu staremu człowiekowi, sprawiedliwemu i pobożnemu, Duch Święty objawił, że zobaczy Mesjasza. I on zobaczył nie tylko Mesjasza, ale również Jego Matkę. Dlatego na cześć Mesjasza wyśpiewał kantyk, a Matce błogosławił i przekazał Jej proroctwo. Podobną drogą doszła do Maryi anonimowa niewiasta ewangeliczna, zafascynowana słowami i czynami Jezusa wypowiada pod adresem Jego Matki błogosławieństwo ${ }^{17}$.

15 Por. T. Lewandowski, Kaznodziejstwo maryjne, dz. cyt., s. 45n.

16 Por. W. Siwak, „Przez Jezusa do Maryi" według Jana Pawła II, red. S. C. Napiórkowski i K. Pek, Częstochowa-Licheń 2002, s. 164n.: L. Szewczyk, Przez Jezusa do Maryi w kaznodziejstwie, w: Przez Jezusa do Maryi..., dz. cyt., s. 113n.; J. Twardy, Głoszenie kazań maryjnych, w: Kościół czci Matkę swego Pana, red. W. Siwak, Przemyśl 2003, s. 156.

17 J. Kudasiewicz, Oto Matka Twoja..., dz. cyt., s. 90n. 
Odnajdując pełny obraz Chrystusa, odnajdujemy w Ewangelii także biblijny obraz Maryi. Bóg realizuje swój plan zbawienia i u jego szczytu (Gal 4, 4) obecna jest Maryja. Dzięki Jej macierzyństwu Syn Boży istniejący odwiecznie u Ojca wchodzi w ludzkie dzieje. MaryjaMatka potwierdza realność człowieczeństwa Chrystusa. Bóg, powołując Ją do swoich planów, obdarzył Ją szczególną łaską („pełna łaski, Pan z Tobą"). Bóg chciał, aby przyjście Zbawiciela poprzedziła zgoda Tej, która przewidziana była na Matkę. Maryja ochoczo przyjęła Boże plany i od początku czynnie współpracuje w dziele zbawienia swego Syna: ukazuje Syna pasterzom i mędrcom, przedstawia Jezusa w świątyni, wypełniając Prawo. W znamienny sposób pojawia się na początku misji Jezusa w Kanie Galilejskiej. Nie bez postanowienia Bożego stanęła pod Jego krzyżem, „najgłębiej ze swym Jednorodzonym współcierpiała i ofiarą Jego złączyła się matczynym duchem" $(\mathrm{KK}, 58)^{18}$.

$\mathrm{Na}$ wybranie i powołanie przez Boga na Matkę Jego Syna, na obdarowanie łaską, Duchem Świętym, Maryja odpowiedziała wiarą, dyspozycyjnością oraz modlitwą wyrażoną w Magnificat. Ta modlitwa mówi o doświadczeniu Boga, który jest Panem i Zbawcą, ale i pełnym miłosierdzia. Ona doświadczyła tego miłosierdzia i stała się jego głosicielką, wychwalając Boga za wielkie rzeczy, jakie Jej uczynił ${ }^{19}$.

Ewangelie ukazują Maryję jako autentyczną słuchaczkę słowa Bożego. Maryja jest prawdziwą Bogarodzicą, ale i entuzjastyczną Nosicielką Boga do ludzi (nawiedzenie). Jej spotkanie z Bogiem owocuje spotkaniem z człowiekiem. Łukasz zwraca szczególną uwage na wielkość i godność Syna Maryi. Eksponując chwałę i godność Jezusa, przysparza także czci Jego Matce. Łukasz podkreśla wielkość Syna Maryi w ten sposób, że odnosi do Niego te tytuły, które Stary Testament przypisywał samemu Bogu. Matka takiego Syna zasługuje

18 Por. tamże, s. 53n.

19 Por. tamże, s. 49, 106n. 
na tytuł Matki Bożego Syna. W scenie odnalezienia Jezusa w świątyni Maryja jawi się jako ewangeliczny wzór szukania Jezusa. Ewangeliczna istota nabożeństwa do Maryi polega właśnie na szukaniu z Nią Jezusa i odnajdywaniu Go. Z Maryją idziemy do jedynego Pośrednika. Ona zrodziła Słowo Wcielone - jedynego Pośrednika i Zbawiciela i dzięki temu zasługuje na tytuł Pośredniczki. Jest Pośredniczką zbawienia, bo przez Nią przyszedł Zbawiciel. Uczestnicząc w pośrednictwie Syna, „Wspiera macierzyńską opieką wiernych, by przylgnęli do Pośrednika i Zbawiciela" (RM 38). Jej pośrednictwo ma charakter wstawienniczy, jest ono skierowane do Chrystusa i zmierza do objawienia Jego chwały. W Kanie Galilejskiej jawi się w służbie ewangelicznego radykalizmu: „Cokolwiek mój Syn wam powie, czyńcie” 20.

Maryja doskonale zjednoczona z Chrystusem w Jego wyniszczeniu, przez wiarę uczestniczy w śmierci Syna, a jest to śmierć odkupieńcza. W testamencie z krzyża Jej macierzyństwo cielesne w stosunku do Jezusa przedłuża się w macierzyństwo duchowe w stosunku do wierzących w Chrystusa, to jest do Kościoła ${ }^{21}$.

Niezwykle istotna jest korelacja Duch Święty-Maryja. Dobrze ukazane relacje Maryi do Ducha Świętego stanowią pełniejsze wyjaśnienie Jej udziału w tajemnicy Chrystusa. Ewangelia jest świadectwem nieustannego uczestnictwa Ducha Świętego w wydarzeniach z życia Maryi. On jest Tym, który obdarza i kształtuje Maryję. Jak podkreśla ks. Siwak, w życiu Maryi Duch Święty objawia się jako Duch świętości (tajemnica Niepokalanego Poczęcia), Dawca życia (zwiastowanie), Duch proroctwa i radości (nawiedzenie), Duch ofiarowania (ofiarowanie Jezusa), Duch przemieniającej Miłości (Kana), Duch mocy i siły (Maryja pod krzyżem), Duch modlitwy i jedności (Zesłanie Ducha Świętego). Maryja jest szczególnie umiłowana przez Ducha Świętego, obdarzona Jego najgłębszą miłością i odpowiadająca

20 Tamże, s. 61-68.

21 Por. tamże, s. 69-77. 
miłością oblubieńczą („Oblubienica Ducha Świętego”) ${ }^{22}$. Maryja jawi się jako wzór korzystania z charyzmatu. We Wcieleniu przyjmuje charyzmat, bo macierzyństwo Boże jest charyzmatem, darem dla innych; Maryja przyjmuje Jezusa, by dawać Go innym, dawać Go Kościołowi ${ }^{23}$. W zwiastowaniu Maryja czynnie uczestniczy w zawarciu Nowego Przymierza, staje się pierwowzorem osobistego przymierza między Bogiem i człowiekiem. Między Duchem Świętym a Maryją istnieje głęboka jedność, jest oddana Duchowi Świętemu najbardziej ze wszystkich ludzi. Duch Święty i Maryja są wspólnie płodni: „znalazła się brzemienną za sprawą Ducha Świętego" (Mt 1,18) i Ten, którego poczęła w swoim ciele „jest z Ducha Świętego” (Mt 1, 20).

Tajemnica Chrystusa trwa i urzeczywistnia się w tajemnicy Kościoła, dlatego też należy właściwie ukazywać powiązania misterium Maryi i Kościoła. Maryja jest pośród nas i z nami w Kościele. A ponieważ jest w szczególny i niepowtarzalny sposób związana z Chrystusem, posiada też niepowtarzalne i szczególne miejsce w Kościele. Maryja jest członkiem Kościoła, ale ze względu na swój macierzyński związek z Jezusem jest członkiem niezwykłym. Jest prawzorem Kościoła „w porządku wiary, miłości i doskonałego zjednoczenia z Chrystusem" (KK 63). Jest pierwowzorem Kościoła jako dziewica oddana w pełni Bogu i jako matka rodząca Chrystusa. Będąc wzorem Kościoła, nie staje ponad nim, lecz jest jego najdoskonalszym członkiem. Taka wizja Maryi, jako zrealizowanego ideału Kościoła, pozwala w nowej perspektywie zobaczyć dogmaty maryjne: o Niepokalanym Poczęciu Maryi i o Jej Wniebowzięciu. W tajemnicy Niepokalanego Poczęcia Maryja zostaje wyróżniona przez niezwykłą drogę odkupienia, a to wyróżnienie świadczy o Jej bliskości z Jezusem i jest owocem tego najściślejszego związku. Podobnie

22 G. M. Bartosik, Maryja ikonq Ducha Świętego według Bruno Forte, w: Duch Święty a Maryja, red. S. C. Napiórkowski, T. Siudy i K. Kowalik, Częstochowa 1999, s. 154; W. Siwak, O poprawną teologicznie ikonę Maryi..., dz. cyt., s. 283.

23 W. Siwak, Jaka ikona Maryi..., dz. cyt., s. 178n. 
jawi się nauka o wniebowzięciu Maryi, czyli dopełnieniu Jej chwały w niebie. Ten przywilej nie rozrywa ścisłej więzi Maryi z Jezusem lecz w pełni z niej wynika ${ }^{24}$.

Ukazując Maryję jako wzór Kościoła, należy podkreślać nie tylko fakt obdarzenia Jej łaską, ale także Jej współpracę, przez całe Jej życie oddane bez reszty Bogu. Jest więc Ona wzorem Kościoła w sensie ontologicznym i osobowym. Bóg wybiera Maryję, uświęca i powołuje do współpracy ze sobą, a Ona odpowiada na ten dar zaangażowaniem całego życia ${ }^{25}$.

Drugi rodzaj odniesienia Maryi do Kościoła to Jej macierzyństwo wobec Kościoła, wyrażone w tytule „Matka Kościoła”. Należy podkreślać, że Maryja nie jest ponad Kościołem, ale jest w nim obecna; swoje funkcje i zadania realizuje wewnątrz tajemnicy Kościoła ${ }^{26}$. W kwestii macierzyństwa Maryi w porządku łaski należy właściwie ukazywać problem Jej pośrednictwa. Sobór, a jeszcze wyraźniej Jan Paweł II, pośrednictwo Maryi tłumaczy w sensie wstawiennictwa, przy jednoczesnym przypomnieniu zasadniczej prawdy o jedynym Pośredniku. Trzeba być świadomym prawdy, że łaska nie jest „,rzeczą", ale samym Bogiem, który siebie komunikuje, a zatem nie można mówić o pośrednictwie między Bogiem i nami. Raczej trzeba mówić o uczestnictwie w pośrednictwie Chrystusa. Powiązanie idei pośrednictwa maryjnego z Bożym macierzyństwem, jak to czyni Jan Paweł II, stanowi właściwy punkt wyjścia dla budowania właściwej teologii pośrednictwa. Pośrednicza obecność Maryi w rodzeniu Chrystusa, w misterium paschalnym staje się w jakiś sposób udziałem całego Kościoła i pokazuje, że każdy zbawczy wpływ wywodzi się ze współpracy z Chrystusem i od niego pozostaje zależny.

24 Tenże, O poprawną teologicznie ikonę Maryi..., dz. cyt., s. 283. Por. także, T. Lewandowski, Implikacje homiletyczne..., dz. cyt., s. 68n.

25 Por. W. Życiński, Jak mówić o Maryi, w: Prawdy wiary w przepowiadaniu, red. W. Przyczyna, Kraków 2002, s. 75n.

26 T. Lewandowski, Kaznodziejstwo maryjne.., dz. cyt., s. 42. 
Nie można więc mówić o jakiejkolwiek konkurencji w stosunku do Chrystusa ${ }^{27}$.

Skoro Jan Paweł II mówi o pośrednictwie Maryi jako podporządkowaniu siebie jedynemu pośrednictwu między Bogiem a ludźmi, to preferowany dotąd model pośrednictwa „przez Maryję” nie może stanowić aktualnego elementu kultu. Trzeba więc dotychczasową terminologię („Pośredniczka do Chrystusa”, „Pośredniczka łask wszelkich”, „Współodkupicielka”) zastąpić terminologią bardziej chrystologiczną i eklezjologiczną, podkreślając macierzyński wymiar działania Maryi. Ten macierzyński wymiar pośrednictwa powinien stać się wezwaniem do współodpowiedzialności za Kościół i zaangażowania się w przemianę świata. Maryja współpracująca z Chrystusem uczy cały Kościół, że każdy na swój sposób ma współpracować w dziele zbawienia, każdy człowiek ma swoje zadanie w historii ${ }^{28}$.

27 Tamże, s. 46n.

28 Tamże, s. 47. Ciekawą jest propozycja Józefa Kudasiewicza, aby tak w nauczaniu, jak i kulcie, zwłaszcza w nabożeństwach wyrastających z pobożności ludowej (choćby nabożeństwo do Matki Bożej Nieustającej Pomocy) w pełni zastosować tytuł maryjny "Matka zawierzenia" i "Matka naszego zawierzenia”. Maryja jest Matką, której można całkowicie zaufać, zawierzyć, na której można polegać, na której można w każdej sytuacji się oprzeć. „Historia zbawienia nas uczy, że Matka zawierzenia jest zawsze tam, gdzie jest ciężko, gdzie grozi niebezpieczeństwo, gdzie czyha śmierć. Jest tam, gdzie szczególnie potrzeba Matki, gdzie potrzeba oparcia. Niesie zawsze pomoc, modlitwę, dar Ducha Świętego. Taka była w historii zbawienia, taka jest i dzisiaj" (J. Kudasiewicz, Oto Matka twoja. Biblijny katechizm maryjny, Kielce 2007, s. 101). Świadomość, że Maryi można zawierzyć bez reszty, nie wystarcza. „Wyciągnięcie tylko takiego wniosku byłoby zbyt interesowne i egoistyczne. Jesteśmy Jej dziećmi a nie niemowlętami, które umieją tylko płakać, wyciągać rękę i wołać : «daj!». Być dzieckiem takiej Matki zobowiązuje. [...] Dzieci Matki zawierzenia winny się stawać ludźmi zawierzenia, ludźmi, na których można się oprzeć i polegać, którzy jawią się zawsze tam, gdzie potrzebna jest pomoc. [...] Winniśmy się włączyć w te pokolenia uczniów Jezusa i zabrać do siebie Jego Matkę tak, jak zabrał Ją św. Jan. Co to znaczy dziś zabrać Ja do siebie? Oznacza to zabrać w nasze życie i postępowanie Jej całkowite zawierzenie Bogu [...]. Gdy to wszystko wraz z Nią zabierzemy w nasze życie, to i my staniemy się na Jej wzór ludźmi zawierzenia a nabożeństwo do Matki Najświętszej nie będzie przemijającym uczuciem i łatwowiernością, ale naśladowaniem. My 
W przepowiadaniu należy także jasno ukazać rolę Ducha Świętego w maryjnym pośrednictwie. Nie można dalej posługiwać się terminologią, która może sugerować, że Maryja zastępuje Ducha Świętego. Jan Paweł II mówi o macierzyństwie Maryi jako „macierzyństwie w Duchu Świętym” (RM 43), podkreślając, że źródłem tożsamości macierzyńskiej Maryi jest właśnie działanie tegoż Ducha ${ }^{29}$.

Ostatnią z zaproponowanych korelacji ukazywania Maryi w przepowiadaniu jest perspektywa antropologiczna, która wskazuje, iż Maryja jako stworzenie jest pełnym urzeczywistnieniem ludzkiej godności. Jest więc także wzorem właściwie odczytanego i zrealizowanego powołania kobiety oraz wypełnienia powołania człowieka do świętości ${ }^{30}$.

\section{Końcowe wnioski}

Stosując zasadę powrotu do źródeł, czyli do Objawienia, można powiedzieć, że osoba Maryi jawi się zawsze w jakichś relacjach, nigdy w oderwaniu i izolacji, a wszystkie te relacje koncentrują się w osobie Jezusa Chrystusa jako centrum historii zbawienia. Trzeba zawsze widzieć Maryję w relacji do Boga: została wybrana przez Boga na Matkę Syna Najwyższego; Bóg uczynił Jej wielkie rzeczy, obdarzył łaską i Duchem Świętym. Maryja na to Boże powołanie odpowiedziała wiarą, modlitwą, posłuszeństwem Prawu Pana, uważała siebie za służebnicę Pańską.

również na Jej wzór będziemy się stawać ludźmi zawierzenia, ludźmi na których można się oprzeć" (tamże, s. 102-105). W kontekście tych słów można zgłosić konkretną sugestię związaną z nabożeństwem do MB Nieustającej Pomocy: uczestnicy słyszą bardzo konkretne prośby, które mogą być zrealizowane przez nich samych, przez ich zaangażowanie i to właśnie będzie forma naśladowania Maryi, spieszenie z pomocą konkretnej osobie, w konkretnej sprawie.

29 W. Siwak, O poprawna teologicznie ikonę Maryi..., dz. cyt., s. 283.

30 Tamże, s. 284. 
Biblijny obraz Maryi w szczególny sposób ukazuje Jej ścisły związek z Jezusem, bowiem w Nim i przez Niego spełnia Maryja szczególną rolę w historii zbawienia. Dzięki Jej przyzwoleniu Bóg stał się Człowiekiem, a Ona Matką Zbawiciela. W ten sposób Maryja od chwili dziewiczego poczęcia jest złączona z osobą Syna i Jego dziełem, które ciągle trwa w rzeczywistości Kościoła. Jej obecność w dziele zbawczym trzeba widzieć w podwójnej perspektywie; jako wybranie, wywyższenie ze względu na funkcję jaką ma spełnić oraz świadomość, że jest Ona tylko człowiekiem i jako Matka dzieli losy swego Syna - „uniżenie” i „wywyższenie”. Takie widzenie Maryi w zjednoczeniu z dziełem Syna pozwala mówić o Niej jako przynależnej do rodzaju ludzkiego, postaci historycznej, postaci dzięki której historia nabrała innego wymiaru, bowiem przez Nią rozpoczął się proces „Wzrastania” Chrystusa w dzieje świata.

Teksty biblijne ukazują również Jej związek z Duchem Świętym. On Ją uświęca: kształtuje w Maryi ludzką naturę Syna Bożego. Ona zaś, napełniona Duchem Świętym, niesie Go innym; wyprasza dary Ducha dla Kościoła; jest czcicielką Ojca w Duchu i prawdzie; nie zastępuje Ducha Świętego, lecz do Niego prowadzi i uczy wiernych wrażliwości na natchnienia Ducha Świętego.

Ponieważ tajemnica Jezusa ma swoje przedłużenie w tajemnicy Kościoła, to przekaz biblijny kreśli relacje Maryi do Kościoła, jako wspólnoty: Ona modli się z Kościołem, jest zapowiedzianą w Starym Testamencie Córą Syjonu, jest typem Ludu Przymierza, figurą Kościoła.

Wszelkie próby izolowania Maryi od kontekstu historiozbawczego i trynitarnego są niezgodne z Objawieniem. Kontemplacja osoby Maryi na szerokim tle biblijnym, a szczególnie ewangelicznym, pokazuje Jej głęboki związek z całym orędziem i etosem Dobrej Nowiny. Maryja, podobnie jak Jej Syn, domaga się zachowania całej Ewangelii, wszystkiego, co Jezus powiedział. Maryja nie tylko przypomina orędzie Jezusa, ale również pokazuje, jak trzeba na co dzień nim żyć. 
Realizowanie Ewangelii w życiu na wzór Maryi jest znakiem prawdziwego nabożeństwa. Chodzi więc nie tyle o pobożność „do Maryi”, ale o pobożność „jak Maryja”, czyli „na wzór Maryi”. Należy podpatrywać Jej drogę, jako pierwszej chrześcijanki i przeżywać tajemnicę Boga jak Maryja; przeżywać tajemnicę Chrystusa jak Maryja; otwierać się na Ducha Świętego jak Maryja; słuchać słowa Bożego jak Maryja; być matką duchową jak Maryja, czyli przyczyniać się do rodzenia się oraz dojrzewania dzieci Bożych ${ }^{31}$.

Szczególna cześć oddawana Maryi, jeśli ma być zgodna z kultem czasów mesjańskich, musi mieć wymiar chrystologiczny, tzn. musi być w ścisłym związku z Chrystusem, gdyż z Niego bierze swój początek i skuteczność. I w tym kontekście na szczególną uwagę i wykorzystanie homiletyczne zasługują teksty liturgiczne zawarte w Collectio missarum de Beata Maria Virgine (1986) przedstawiające udział Maryi w historii zbawienia, która kontynuuje swój bieg w cyklu tajemnic Chrystusa w roku liturgicznym ${ }^{32}$.

\section{Chrystocentryzm maryjny w przepowiadaniu}

\section{Streszczenie}

Żeby ukazać aktualne zagadnienia związane z chrystocentryzmem maryjnym w przepowiadaniu trzeba odwołać się do VIII rozdziału Konstytucji dogmatycznej o Kościele Lumen gentium II Soboru Watykańskiego i najnowszych dokumentów Kościoła, zwłaszcza Marialis cultus Pawła VI i Redemptoris Mater Jana Pawła II oraz komentarzy teologicznych. Na ich podstawie będzie można odpowiedzieć na pytanie, jak mówić o Maryi uwzględniając Jej szczególną rolę w zbawczym planie Boga, jednocześnie pamiętając, że przepowiadanie maryjne ma proklamować dzieło Boga w Chrystusie?

31 S. C. Napiórkowski, Pierwsza chrześcijanka i przewodniczka pielgrzymującego Ludu, w: Kościół czci Matkę..., dz. cyt., s. 137n.

32 S. Czerwik, Maryja Dziewica w rocznym cyklu obchodów tajemnic Chrystusa na podstawie "Collectio missarum de Beata Maria Virgine", w: Matka Jezusa pośród pielgrzymującego Kościoła, red. J. S. Gajek i K. Pek, Warszawa 1993, s. 151-174. 
Historiozbawczy obraz Maryi zarysowany w dokumentach Kościoła staje się wyzwaniem dla kościelnej posługi słowa. Treść tych dokumentów stanowi bogate źródło, a jednocześnie zawiera zasady przepowiadania prawd maryjnych. Z tych dokumentów wynika, że właściwa dla przepowiadania ikona maryjna powinna być ikoną biblijną, patrystyczną, liturgiczną i magisterialną. Nauczanie o Maryi musi posiadać nieustanne odniesienie do historii zbawienia, czyli pozostawać w perspektywie ukazującej Ją w relacji do Trójcy Świętej i do Kościoła, czyli w oparciu o zasadę korelacji. Żeby dobrze zrozumieć i właściwie ująć w przepowiadaniu zwłaszcza korelacje Syna i Matki, należy ukazywać pełny obraz Jezusa Chrystusa i ewangeliczny obraz Maryi. W centrum poprawnie ukształtowanej świadomości chrześcijanina musi stać Jezus Chrystus, Jego zbawcze misteria. W nich należy szukać obrazu Maryi („Przez Chrystusa do Maryi"). Odnajdując pełny obraz Chrystusa, odnajdziemy w Ewangelii także biblijny obraz Maryi. Ponieważ tajemnica Jezusa ma swoje przedłużenie w tajemnicy Kościoła, to przekaz biblijny kreśli Jej relacje do Kościoła, jako wspólnoty: modli się z Kościołem, jest zapowiedzianą w Starym Testamencie "Córą Syjonu", jest typem ludu Przymierza, figurą Kościoła. Kontemplacja osoby Maryi na szerokim tle biblijnym pokazuje Jej głęboki związek z całym orędziem i etosem Dobrej Nowiny. Maryja nie tylko przypomina orędzie Jezusa, ale również pokazuje, jak trzeba nim na co dzień żyć. Realizowanie Ewangelii w życiu na wzór Maryi jest znakiem prawdziwego do Niej nabożeństwa. Chodzi więc nie tyle o pobożność „do Maryi”, ale o pobożność „na wzór Maryi”.

Słowa kluczowe

kaznodziejstwo maryjne, chrystocentryzm, ikona Maryi, zasada korelacji, Maryja jako wzór

\section{Marian Christocentrism in proclamation}

Summary

If you want to show the current issues related to Marian Christocentrism in preaching you need to refer to Chapter VIII of the Dogmatic Constitution of the Church Lumen gentium by the Second Vatican Council and recent documents of the Church, especially Marialis cultus by Paul VI and Redemptoris Mater by John Paul II and some theological comments. On this basis you will be able to 
answer the question: how to speak about Mary taking into account her special role in God's salvation plan, still keeping in mind that Marian preaching is to proclaim the work of God in Christ?

The image of Mary connected with the history of salvation which is outlined in the documents of the Church becomes a challenge for preaching. The content of these documents is a rich source of information, which also contains the rules of proclaiming the truths about the Virgin Mary. These documents show that the correct preaching Marian icon should be a biblical, patristic, liturgical and magisterial icon. The teaching about Mary must have constant reference to the history of salvation, showing her in relation to the Holy Trinity and the Church, which is based on the principle of correlation. If you want to understand and recognize properly the relationship of the Son and the Mother especially in preaching, you should show the complete image of Jesus Christ and the Gospel image of Mary. Jesus Christ and His salvific mysteries must be in the center of the correctly shaped Christian consciousness. You should look for the image of Mary in them ("Through Christ to Mary"). When we find a complete picture of Christ, we will find the biblical image of Mary in the Gospel. As the mystery of Jesus has its reflection in the mystery of the Church, the Bible content shows Her relationship to the Church as a community: Mary is praying with the Church, she is announced in the Old Testament "Daughter of Zion"; she is the type of people of the Covenant, figure of the Church. The contemplation of the person of Mary in a broad background of the Bible; shows her deep connection with the whole message and the ethos of the Good News. Mary not only recalls the message of Jesus, but also shows how you need "live Him" every day. If you fulfill the Gospel like Mary in your life it is a sign of true devotion to her. It is not so much about the devotion "to Mary", but about the devotion, "like Mary" as a model as a paradigm of Christian life.

Keywords

Mary, preaching, Christocentrism, icon of Mary, the principle of correlation

\section{Bibliografia}

Cantalamessa R., Maryja zwierciadłem dla Kościoła, przeł. J. Królikowski, wstęp A. Kiejza. Warszawa 1994. 
Cześć Maryi dzisiaj. Propozycje pastoralne, red. W. Beinert, przeł. M. Węcławski, wstęp W. Miziołek, Warszawa 1992.

Forte B., Maryja. Ikona tajemnicy, przeł. B. Widła, Warszawa 1999.

Ikona Liturgiczna. Ewangelizacyjne przesłanie ikonografii maryjnej, red. K. Pek, Warszawa 1999.

Kudasiewicz J. Witczyk H., Kontemplacja Chrystusa - Ikony miłosiernego Ojca. Medytacje biblijno-kerygmatyczne, Kielce 2002.

Kudasiewicz J., Oto Matka twoja. Biblijny katechizm maryjny, Kielce 2007.

Laurentin R., Matka Pana. Krótki traktat teologii maryjnej. Wydanie integralne, przeł. Z. Proczek, Warszawa 1989.

La Potterie, I. de, Maryja w tajemnicy Przymierza, przeł. A. Tronina, Warszawa 2000. Siwek G., Kazania maryjne, Kraków 2001.

Scheffczyk L., Maryja. Matka i Towarzyszka Chrystusa, tłum. J. Tumielewicz, Kraków 2004.

Thurian M., Maryja Matka Pana, figura Kościoła, przeł. E. Ogiński, Warszawa 1990 